\title{
Effect of Sedentarization on Social Services Available to Pastoral Fulanis in Abeokuta North Area of Ogun State
}

Adebayo, $\mathrm{K}^{1}$. Osuntade, O. B ${ }^{1}$. and Ayankoya, E. O. ${ }^{2}$

1. Natural Resources Institute, University of Greenwich, Chatham, United Kingdom

2. Department of Agricultural Extension and Rural Development, University of Agriculture, Abeokuta, Nigeria

\begin{abstract}
The study examined the demographic characteristics of the pastoral Fulanis, length of stay in their current location as well as access to formal education and other social services. Primary data were collected from 80 pastoral Fulanis in Alamala Adehun, Mologede and Obete villages selected by simple random sampling techniques. Chi-square analysis was used to test two null hypotheses. It was found that there were no significant relationships between respondents' demographic characteristics (age, marital status, sex, educational level and household size) and their length of residence on the one hand and social services enjoyed and length of residence on the other. It was discovered that sedentarisation contributed to livelihood diversification into crop farming and petty trading but has not influenced the social services enjoyed. It was recommended that pastoral Fulanis should be provided with adequate extension services and social facilities, such as education, water supply, electricity, adequate transportation and farm credit. This will contribute effectively to the agricultural development of Nigeria.
\end{abstract}

Key words: Sedentarization, Social services, Pastoral Fulanis

\section{INTRODUCTION}

Over several centuries, the Fulanis have developed a herding system that withstands conditions of tropical rain, heat, humidity and the dusty-dry Hamattan season. This herding system is widely known as nomadism. In this system, the migrant Fulanis often come across life-threatening hindrances such as drought, diseases, tribal enemies, and cattle thieves. The encroachment on grazing land and cattle-route by the land hungry farmers expose the animals to potential starvation. One of the promising responses to these challenges by the nomadic Fulanis is a gradual process of sedentarization. Sedentarization is the act of settling down. It also implies the process of moving from the nomadic to a settled way of life. In this evolving process, the primary occupation of the Fulanis remains cattle herding supplemented by farming at various locations in the southern end of the old nomadic route. These new settlements also offer resting places and link with local population for Fulanis herdsmen who keep the nomadic tradition. Current studies have shown that about a tenth of the Fulanis population found in southwest Nigeria have jobs other than herding or farming (Omotayo et al., 2005); even though these non herding jobs are seasonal and opportunistic. For instance, during wet season the Fulanis 


\section{Journal of Agricultural Extension}

Vol. 12 (1) June, 2008

take advantage of the high manure presence in their cattle-holding paddocks to plant corn, sorbet, millet and raise vegetables in their backyards. The resulting farm stubble is also fed to animals as supplementary feed. In these emerging settlements, domestic responsibilities fall on the women who process and cook the food. Girls and women weave mats, spin cotton into thread, make household decoration and collect herbs and vegetables. They also buy food from market, milk the cow, churn the milk and make butter. They sell milk and butter and do craftwork such as decorating calabashes (Riesman, 1997 and Fricke, 1979). Women and girls are also responsible for cleaning the compound; growing vegetables, raising poultry and nonruminant stock, handling disabled animals, fetching water, collecting firewood, help in making temporary shelter, as well as bearing and nurturing the children (Vengorff, 1980 and Awogbade, 1983).

Since 1976, a process stressing the human aspects in pastoralism began in Nigeria. The Fulanis Amenities Program (1976), the Land Use Act (1976) and Nomadic Education Programmes (1986) are examples of the new approaches that seek to address the issues of human capital development among the Fulanis. Despite these efforts, the Fulanis are among the most neglected of Nigerian ethnic groups (Bonfiglio et. al., 1993). The challenges faced by the Fulanis herdsmen range from environmental limitations, absence of formal education, problem of mobility, land use limitation, failure to implement government programmes properly, stereotyping and lack of access to formal credit. The absence of men and women with high levels of Western education among the herdsmen has put the Fulanis at the mercy of more educated ethnic groups in Nigeria. Against this background, this study intends to:

1. Examine the evolving process of sedetarization

2. Determine its propensity to avail the settled Fulanis greater access to social services

3. Determine if the longer the Fulanis stay in a place of residence the higher the level of social services they will enjoy.

\section{METHODOLOGY}

The study was conducted in Abeokuta North Local Government Area of Ogun State among pastoral Fulanis. Simple random sampling technique was used to select 20 Fulanis households from four (4) purposively selected locations namely Alamala, Adehun, Molegede and Denro Settlements. These settlements are the main locations of settled Fulanis along the old nomadic route passing through Ogun State. A sample size of 80 individual pastoralists was drawn from the selected households.

Primary data on demographic characteristics, social services enjoyed and the length of stay in the selected locations were obtained through the use of an interview schedule. The variables obtained include:

1. Age measured in categories as $18-24,25-34,35-44$ or 45 and Above

2. Marital status measured as married or single

3. Sex measured male or female

4. Educational level measured as No Formal Education, Incomplete Primary Education, Qur'anic, Complete Primary/Qur'anic or Post Secondary/ Qur'anic 
5. Household size measured in categories as $1-4$ persons, $5-8$ persons or Above $9-12$

6. Length of stay by pastoral Fulanis in the current settlement measured in years

7. Number of cattle owned measured in categories as $11-15$ heads, $16-20$ heads, or Above 20 heads

8. Sources of replacement stock measured as Old stock, nearby market, Directly from Northern Nigeria or nearby market + old stock

9. Other source of income measured as Crop Farming Alone, Sheep + Goat + Crop farming, Wage Alone, Wage + Crop Farming, Goat Alone or Crop farming + Goat

10. Key constraints faced by pastoral Fulanis in setting down obtained as responses to an open-ended question

11. The Social Services enjoyed by pastoral Fulanis measured as Market, Bank/credit facility, Hospital/healthcare, Veterinary services, Pasture, School or Electricity

12. Livestock Treatment used by Pastoral Fulanis interviewed measured as Traditional or Veterinary services

The data was analyzed with descriptive statistics such as pie charts, bar charts, frequency distribution, percentages and mean. Chi-square analyses were used to test the null hypotheses in the study.

\section{RESULTS AND DISCUSSION}

\section{Description of respondents}

Most of the pastoral Fuanis interviewed (57.5\%) were between 35-44 years age category, $97.5 \%$ were married while $97.5 \%$ were male, $66.3 \%$ had no formal education and $66.7 \%$ had $1-4$ person household size (Table 1). Similar findings reflecting young, married Fulanis with low household sizes were found in Omotayo et al., $(2005 ; 2006)$. The prevalence of male in the sample may however be due to the patrilineal nature of the Fulanis society which makes it almost impractical for an outsider, including researchers, to sit a woman down for a formal or semi-formal interview Riesman (1977). In addition, Table 1 shows some characteristics of these Fulanis group. They own more than 20 heads of cattle (96.3\%); obtain replacement from old stock $(75.0 \%)$ and earn additional income mainly from crop farming alone $(68.9 \%)$. It is noteworthy however that an emerging group among settled Fulanis $(6.3 \%)$ is now earning additional income from wages (Table 1 ).

\section{The sedentarization process and factors affecting it}

The Fulanis are traditionally a group of West African pastoralists. They move over vast areas and cross many cultures from the Sene-Gambia through the grasslands of the Sudan (Stenning 1959). However, in course of time some Fulanis began to break away from this distinctive nomadic pastoralism to settle as they were converted to Islam. But the prevalence of stereotyping in cultural relations has 
underplayed the characteristics of the settled Fulanis in any discussion about the Fulanis (Omotayo et al., 2005). Figure 1 shows that the majority of the respondents $(97.5 \%)$ have settled in their current settlement for more than 11 years, yet some new settlers were found $(2.5 \%)$ who came in between 1 to 5 years ago.

Settling down has not been without its pain however. As shown in Figure 2, the main constraints to settling down are disease infestation, distance to nearby towns and social services as well as hostility from local communities. Even though, diseases alone were reported by only $1 \%$ of the respondents, it was mentioned by all except the two women included in the sample. Even though, studies on conflict between Fulanis settlers and the local farmers have dominated the literature (Omotayo, et al, 2005; Waters-Bayer and Taylor-Powell 1986; Awogbade, 1982) it was mentioned by $44 \%$ of the respondents. The concern for distance to nearby towns and social services gained more prominence as mentioned by $97 \%$ of the respondents. 
TABLE 1: Socio-economic characteristics of the pastoral Fulanis $(n=80)$

\begin{tabular}{|c|c|c|}
\hline \multirow{2}{*}{\multicolumn{3}{|c|}{$\begin{array}{l}\text { Parameters } \\
\text { Aqe (Yrs) }\end{array}$}} \\
\hline & & \\
\hline $18-24$ & 1 & 1.3 \\
\hline $25-34$ & 12 & 15.0 \\
\hline $35-44$ & 46 & 57.5 \\
\hline 45 and Above & 20 & 25.0 \\
\hline No Response & 1 & 1.3 \\
\hline \multicolumn{3}{|l|}{ Marital status } \\
\hline Married & 78 & 97.5 \\
\hline Single & 2 & 2.5 \\
\hline \multicolumn{3}{|l|}{ Sex } \\
\hline Male & 78 & 97.5 \\
\hline Female & 2 & 2.5 \\
\hline \multicolumn{3}{|l|}{ Educational level } \\
\hline No Formal Education & 53 & 66.3 \\
\hline Incomplete Pry. Education & 1 & 1.3 \\
\hline Qur'anic & 24 & 30.0 \\
\hline Post Secondary/Qur'anic & 1 & 1.3 \\
\hline Complete Primary/Qur'anic & 1 & 1.3 \\
\hline \multicolumn{3}{|l|}{ Household size } \\
\hline $1-4$ & 10 & 66.7 \\
\hline $5-8$ & 3 & 20.0 \\
\hline Above $9-12$ & 2 & 13.33 \\
\hline \multicolumn{3}{|l|}{ Number of cattle owned } \\
\hline $11-15$ & 2 & 2.5 \\
\hline $16-20$ & 1 & 1.3 \\
\hline Above 20 & 77 & 96.3 \\
\hline \multicolumn{3}{|c|}{ Sources of replacement stocks } \\
\hline Old stock & 60 & 75.0 \\
\hline Nearby market & 13 & 16.3 \\
\hline Directly from North & 2 & 2.5 \\
\hline Nearby market + old stock & 3 & 3.8 \\
\hline No Response & 2 & 2.5 \\
\hline \multicolumn{3}{|l|}{ Other source of Income } \\
\hline Crop Farming Alone & 55 & 68.9 \\
\hline Sheep + Goat + Crop farming & 8 & 10.0 \\
\hline Wage Alone & 1 & 1.3 \\
\hline Wage + Crop Farming & 4 & 5.0 \\
\hline Goat Alone & 1 & 1.3 \\
\hline Crop farming + Goat & 1 & 1.3 \\
\hline No Response & 10 & 12.5 \\
\hline
\end{tabular}

Source: Field Survey, 2007 


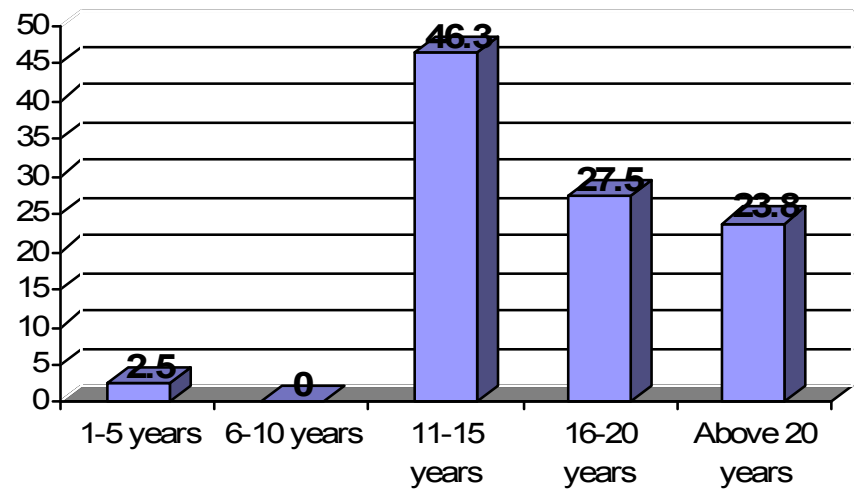

Figure 1: Bar chart distribution of pastoral Fulanis on the length of time stayed in the current settlement

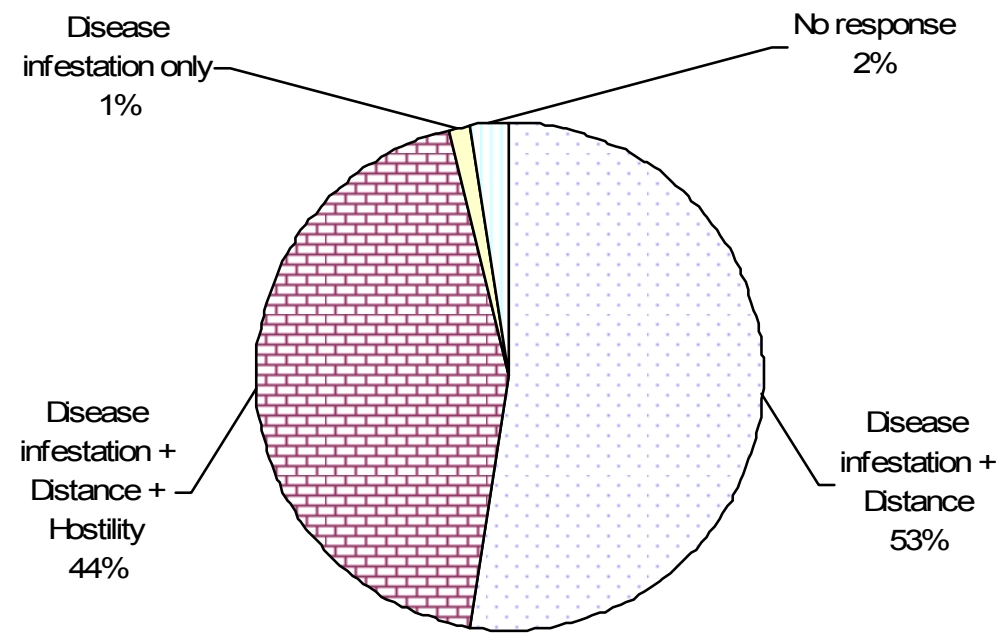

Figure 2: Pie chart distribution of pastoral Fulanis based on the key constraints faced in setting down $(n=80)$

\section{Social services enjoyed by pastoral Fulanis}

Majority of the respondents (90\% and $100 \%$ respectively) admitted that they enjoy healthcare facilities and good pasture for their animals (Figure 3). While the search for good pasture is the primary reason for choice of locations to settle down by Fulanis, the case of healthcare services enjoyed is rested on the ability of the Fulanis to pay for private medical facilities which abound in nearby villages, towns and urban centres.

However, Figure 3 also shows that $20.4 \%$ of the pastoral Fulanis interviewed claim to have access to veterinary services. It is noteworthy however that no veterinary service is located in or around their settlement. The pastoral Fulanis have to move to nearby towns and urban areas to procure drugs for their cattle.

Similarly, access to market, bank and credit faculties are enjoyed by only $20.4 \%$ and $27.4 \%$ respectively. The import of these is that the potential contributions of the Fulanis to the formal economy in Nigeria are currently under-tapped. Monies 
generated from their business transactions often go unreported in the nation's per capita income. The provision of market and banking facilities are therefore an untapped opportunity for the nation.

Furthermore, Figure 3 also shows that $(96.2 \%)$ of the respondents interviewed has no access to formal education. This implies that the pastoral Fulanis have no access to school and even the ones that claim to have access $(3.8 \%)$ have to travel long distances to the nearest schools.

Finally, the situation with electricity is the most drastic. None of the respondent enjoy electricity services. This is not surprising however, given that Nigerians in many urban and rural locations are not satisfied with electricity supply.

On further probe, it was revealed that about $68.8 \%$ visit veterinary doctors/services while $25 \%$ make use of traditional way in treating their affected cattle (Figure 4).

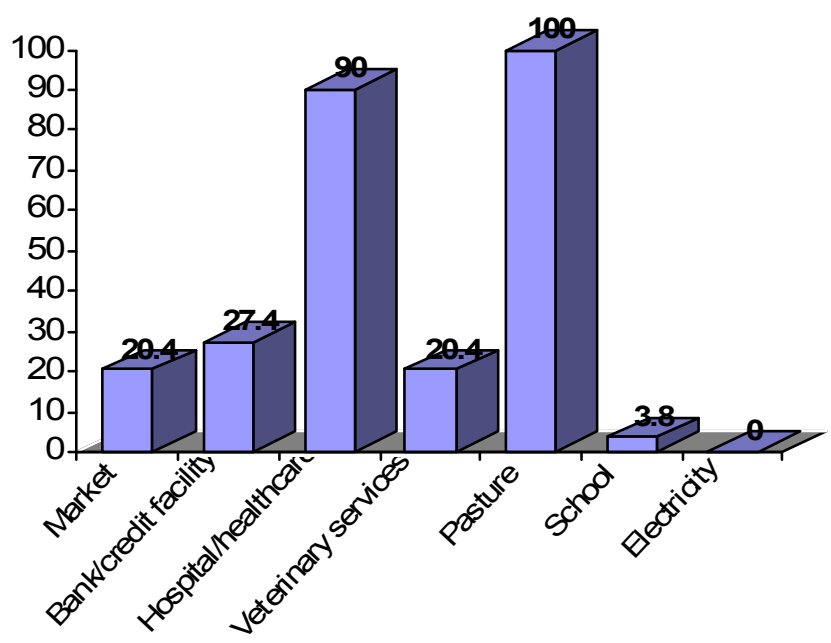

Figure 3: Bar chart distribution of pastoral Fulanis based on the Social Services enjoyed $(n=80)$

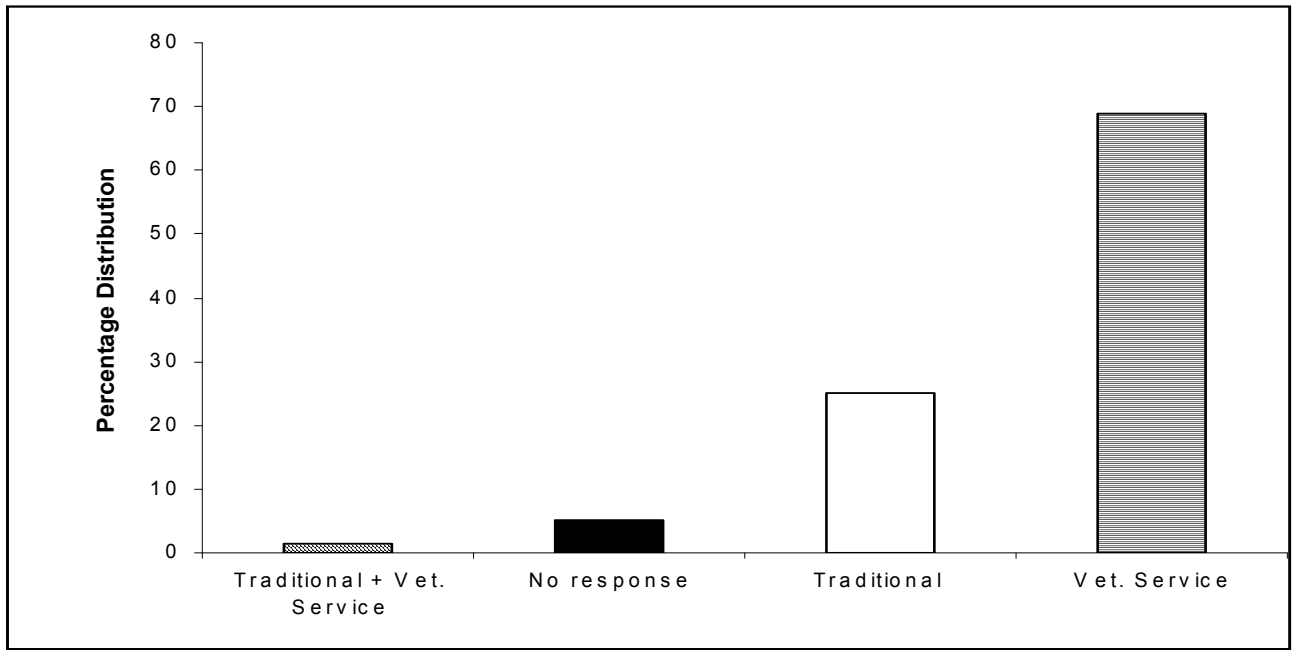

Figure 4: Bar chart distribution of livestock treatment by pastoral Fulanis $(n=80)$ 
Journal of Agricultural Extension

Vol. 12 (1) June, 2008

\section{Dependence of socio-economic characteristics of the Pastoral Fulanis on length of residence}

The resulf shows that the length of time that pastoral Fulanis are resident in their current abode is independent of selected socio-economic characteristics. As shown in Table 2, the null hypotheses cannot be rejected for age, marital status, education and sex. It appears that length of residence in current abode is independent of these characteristics. The case is however different for household size. It appears that length of residence is dependent on household size. A closer look at the contingency table for household size and length of residence shows that pastoralists with larger household sizes tend to stay longer in a place of abode. This may be due to increasing difficulty of moving a larger household in the nomadic tradition.

As shown in Table 3, of all the social services enjoyed by the Fulanis, the null hypotheses was rejected only in the case of access to market. It appears that access to market is dependent on length of residence. It seems that the longer the Fulanis stay in a place of abode, the greater their access to market. Similar relationships cannot be assumed for their access to hospital, veterinary services, schools as well as bank and credit facilities. The Chi-square analyses cannot be run for access to electricity which nobody claims to enjoy and access to pasture which is enjoyed by all respondents.

TABLE 2: Results of Chi-square analyses to determine the dependence of socio-economic characteristics of the Pastoral Fulanis on their length of residence

\begin{tabular}{lcccc}
\hline \multicolumn{1}{c}{ Variables } & $\mathbf{X}^{\mathbf{2}}$ calculated & $\mathbf{d f}$ & $\mathbf{p}$ & Decision \\
\hline Age & 17.48 & 12 & 0.13 & Do not reject Ho \\
Marital status & 2.38 & 3 & 0.50 & Do not reject Ho \\
Educational level & 5.17 & 12 & 1.00 & Do not reject Ho \\
Household size & 61.48 & 6 & 0.03 & Reject Ho \\
Sex & 0.92 & 3 & 0.82 & Do not reject Ho \\
\hline
\end{tabular}

Source: Field Survey and Chi-square calculated

$X^{2}$ calculated $=$ Chi-square calculated

$p=$ Probability level

$d f=$ Degree of freedom 
TABLE 3: Results of Chi-square analyses to determine the relationship between social services enjoyed and the length of residence of Pastoral Fulanis

\begin{tabular}{lcccc}
\hline \multicolumn{1}{c}{ Variables } & $\mathbf{X}^{2}$ calculated & Df & $\mathbf{p}$ & Decision \\
\hline Market & 13.67 & 3 & 0.00 & Reject Ho \\
Hospital & 2.38 & 3 & 0.50 & Do not reject Ho \\
Veterinary service & 2.02 & 3 & 0.57 & Do not reject Ho \\
School & 3.62 & 3 & 0.31 & Do not reject Ho \\
$\begin{array}{l}\text { Bank / Credit } \\
\text { facility }\end{array}$ & 2.38 & 3 & 0.50 & Do not reject Ho \\
Sour & & & &
\end{tabular}

Source: Field Survey and $X^{2}$ calculated, 2007.

$X^{2}$ calculated $=$ Chi-square calculated

$p=$ Probability level

$d f=$ Degree of freedom

\section{CONCLUSION}

It can be concluded that length of residence is independent of the most of the demographic characteristics of the pastoral Fulanis. Similarly, irrespective of their length of stay, sedentarisation does not appear to have engendered greater access to social services enjoyed by pastoral Fulanis. It was discovered that sedentarisation contributed to livelihood diversification into crop farming and petty trading but has not influenced the social services enjoyed. It was recommended that pastoral Fulanis should be provided adequate extension services and treated as key stakeholders in the provision of social facilities, such as education, water supply, electricity, adequate transportation and provision of farm credit. Considering the role that Pastoral Fulanis play in nation's economy, it is essential that they should have:

- Social facilities such as water supply, electricity, amongst others should be provided so as to improve their standard of living and enhance their contribution to agricultural development thus improving national economy.

- Adequate transportation facilities should be provided for them by constructing good road that would link their settlements to the major markets to enhance good marketing activities.

- Farm credit: Fulanis must be assisted to overcome the problem of lack of capital so that they can take advantage of new developments in farming techniques. This can be done by establishing a revolving loan scheme for granting small seasonal loans in cash or kind to needy ones. The loans can be recovered inform of farm produce immediately the crop are harvested or through sales of their cattle.

- Supply of agricultural input: As an incentive government should make available to pastoral Fulanis essential agricultural input e.g. improved seeds, veterinary services amongst others. 
- Agricultural training programme: Attention must be given to the training of pastoral Fulanis by extension officers for the pastoral Fulanis to adopt recommended technology and achieve desired levels of production.

- Co-operative societies: Every effort should be made to promote the formation of co-operative societies by the pastoral Fulanis. They should be encouraged to join existing co-operative associations or form new producer - oriented agricultural co-operatives that can qualify them to receive necessary assistance from the government and financial institutions in order to increase their production capacity.

The implication of all these for policymakers is that a conscious effort need to the placed in addressing sector-specific needs of different stakeholders in the agricultural sector. Pastoral Fulanis constitute an important group of livestock farmers in Nigeria. Efforts to improve their living conditions through the provision of essential social services will contribute effectively to the agricultural development of Nigeria.

\section{References}

Awogbade, M. (1982). "Project to settle pastoral Fulanis: The case study of Rumakikar - Jangarai, Kaduna State Nigeria." C.S.E.R Research Report. No. 9

Awogbade, M. (1983). Fulanis Pastoralism: Jos case study. Zaria, Ahmadu Bello University Press.

Bonfiglio, M. (1993). Agro-pastoralism in Chad as a strategy for survival: An Essay on the Relationship between Anthropology and Statistics, Washington, D.C. World Bank, Technical paper. No. 214.

Fricke, W. (1979). "Cattle husbandry in Nigeria: A study of its Ecological conditions and social-geographical differentiations. "Translated by Hellen and Gordon Cockburn. Heidelberg: n.p.

Omotayo, A. M., Dipeolu, M. A. and Ekpo, U. F. (2005). Health Consequences of Lifestyle Changes among Pastoralists in Southwest Nigeria: A Research Report submitted to The Welcome Trust. University of Agriculture, Abeokuta.

Omotayo, A. M., Ekpo, U. F. and Dipeolu, M. A. (2006). "Health status and health services usage among settled Fulanis pastoralists in Southwest Nigeria". Paper presented at the International Conference on the Future of Transhumance Pastoralist in West and East Africa. November 21-25, 2006. Women Development Centre, Abuja.

Riesman, P. (1977). Freedom in Fulanis Social Life; An Introspective Ethnology Translated by Martha Fuller, Chicago: The University of Chicago Press.

Stenning, D. (1959). Savannah Nomads: A Study of the Woodaabe Pastoral Fulanis of Western Borno province Northern Region, Nigeria. London: Oxford University Press. 
Vengroff, R. (1980). "Upper Volta. Environmental Uncertainty and Livestock production. Texas.

Waters - Bayer, A and E. Taylor-Powell (1986). "Population and Land use in the sub-humid zone of Nigeria". In: R. Von Kaufmann, S. Chater and R. Blench (eds.) Livestock Systems Research in Nigeria's sub humid Zone: Proceedings of a second I.L.C.A./N.A.P.R.I. Symposium held in Kaduna Nigeria, October 29 - November 4, 1984. pp. 37-58. Addis Ababa: I.L.C.A. 